\title{
DAMPAK FENOMENA EXPERIENTIAL MARKETING PADA LOYALITAS PELANGGAN OUTLET WAXHAUS PLAZA SEMANGGI
}

\author{
Aruna Pharahita Sunarto \\ Universitas Pendidikan Indonesia \\ aruna.pharahita@gmail.com \\ Rd. Dian H Utama \\ Universitas Pendidikan Indonesia \\ dianherdianautama@Upi.com
}

\begin{abstract}
ABSTRAK
Tujuan- Seberapa besar gambaran experiential marketing dan loyaltitas pelanggan di Outlet Waxhaus Plaza Semanggi, serta besarnya pengaruh experiential marketing terhadap loyalitas pelanggan Outlet Waxhaus Plaza Semanggi.

Desain/metodologi/pendekatan- Jenis penelitian yang digunakan adala deskriptif dan verifikatif, dengan jumlah sampel sebanyak 93 responden. Teknik analisa data yang digunakan adalah path analysis.

Temuan- Dari penelitian terhadap pengujian hipotesis dapat diketahui bahwa di Outlet Waxhaus Plaza Semanggi experiential marketing berada pada kategori cukup tiggi dan loyaltais pelanggan berada pada kategori tinggi, serta 67,8 persen experiential marketing berpengaruh terhadap loyaltias pelanggan Outlet Waxhaus Plaza Semanggi.

Orisinalitas- Perbedaan ditemukan dalam objek penelitian, periode penelitian, alat ukur dan hasil penelitian. Penulis juga menambahkan teori dari jurnal asing dan buku asing
\end{abstract}

Kata Kunci : Experiential Markeing, Loyalitas Pelanggan

Tipe Artikel : Penelitian

\section{PENDAHULUAN}

Potensialnya perkembangan industri salon kecantikan di Indonesia, menjadikan sebuah peluang bagi pelaku bisnis yang telah ada dan menarik bermunculannya pelaku bisnis baru sejenis yang menawarkan pelayanan dengan keunikannya yang berdampak pada semakin kompetitifnya persaingan para pelaku bisnis dan semakin banyaknya opsi konsumen untuk menggunakan jasa perawatan kecantikan.

Seluruh penyedia treatment waxing berusaha memikat para konsumen untuk menggunakan jasa layanannya. Disisi lain dengan terpikatnya konsumen dengan yang ditawarkan oleh pesaing, membuat konsumen yang telah menggunakan disalah satu merek penyedia jasa treatment waxing beralih ke merek lainnya.

Penyedia jasa treatment waxing hair removal dengan berbagai kemampuan yang dimiliki oleh para pelaku bisnis dan berbagai stategi yang diterapkan, terus berupaya memperluas atau meraih pangsa pasar dengan menambah jumlah konsumen yang menggunakan produk layanannya. Namun melihat fenomena yang terjadi walaupun setiap penyedia jasa treatment waxing mampu menarik konsumen untuk menggunakan produk layanannya, dari sisi lain begitu mudahnya konsumen berpindah dari satu merek ke merek lain pada produk sejenis.
Namun perpindahan terbesar berada di Waxhaus dengan 57 persen pelanggan lama atau yang sebelumnya pernah menggunakan layanan treatment waxing di Waxhaus berpindah ke merek lain.

Kepuasan pelanggan (customer satisfaction) tidak selalu memberikan jaminan bahwa konsumen akan loyal. Walaupun konsumen sudah sangat puas terhadap kualitas produk/jasa, ternyata masih banyak juga yang berpindah ke merek lain. Hal ini disebabkan karena diferensiasi di antara merek- merek yang tersedia tidak terlalu signifikan. Sehingga untuk konsumen, tidak ada risiko untuk berpindah merek. Alasan lain mengapa konsumen yang puas tidak selalu loyal, adalah karena adanya suatu tawaran insentif yang menarik dari kompetitor yang sulit untuk ditolak oleh konsumen. Dalam kondisi ini, loyalitas ke merek awal menjadi turun (Mulyadi \& Saktiawati, 2006).

Loyalitas lebih mengacu pada wujud perilaku dan unit-unit pengambilan keputusan untuk melakukan pembelian secara terus menerus terhadap barang atau jasa suatu perusahaan yang dipilih (Purnama \& Afiani, 2008, p. 90).

Untuk meningkatkan kadar loyalitas pelanggan ke tingkat lebih tinggi lagi, loyal client, sekali lagi perusahaan harus meningkatkan 
manfaat yang diberikannya kepada pelanggan (Sumiyati \& Purwanto, 2000).

Salah satu konsepnya dari pemasaran adalah pengalaman (experiential) merupakan hal yang penting dalam pemasaran. Pemasaran tingkat experiential merupakan bentuk pemasaran yang sesuai dengan kondisi saat ini, karena konsumen tidak lagi dipandang sebagai konsumen yang rasional namun konsumen yang emosional, yakni menggunakan emosi dalam menentukan produk (Hurriyati \& Widiastuti, 2008), (Palmeira et al., 2009).

Menurut Schmitt bahwa "mentioned that creating a pleasant experience for customers is key to customer loyalty, and customers who agree on the experiential marketing that they have experienced are more likely to exhibit higher loyalty" menciptakan pengalaman yang menyenangkan bagi pelanggan adalah kunci loyalitas pelanggan, dan pelanggan yang setuju dengan pemasaran pengalaman yang diterimanya lebih memungkinkan untuk menunjukkan loyalitas yang tinggi (Öztürk, 2015).

Berdasarkan latar belakang tersebut, maka penelitian ini dirumuskan kedalam rumusan masalah sebagai berikut:

1) Bagaimana gambaran experiential marketing Outlet Waxhaus Plaza Semanggi.

2) Bagaimana gambaran loyalitas pelanggan Outlet Waxhaus Plaza Semanggi.

3) Seberapa besarnya pengaruh experiential marketing terhadap loyalitas pelanggan Outlet Waxhaus Plaza Semanggi.

\section{KAJIAN PUSTAKA}

Memandang permasalah ekonomi masyarakat yang berubah dan dengan pendekatan pemasaran tradisional tidak lagi cukup untuk memenuhi kebutuhan pelanggan. Sebagai mana yang dinyatakan Schmitt, hal tersebut dikarena pemasaran tradisional yang mengasumsikan pelanggan menjadi rasional pembuat keputusan yang peduli tentang fitur fungsional dan manfaat. Pendekatan pemasaran tradisional agak tidak lengkap, karena alasan emosional ikut mempengaruhi proses keputusan konsumen (Palmeira et al., 2009).

Berdasarkan hal tersebut, menuntut konsep pemasaran akan pengelolaan konsumen yang telah ada, dengan menambahkan suatu emosinal yang bertujuan untuk pengelolaan pengalaman konsumen (customer experience management). Dengan kata lain, perkembangan nilai ekonomi telah mempengaruhi memunculkan konsep pemasaran yang lebih memperhatikan pada pengelolaan pengalaman konsumen.

Experience economy dianggap sebagai fondasi utama untuk customer experience management (Same \& Larimo, 2012). Customer experience management itu sendiri merupakan pengembangan dari customer relationship management (Logahan, 2015).

Experiential markering sebagaimana yang dinyatakan Schmitt adalah, suatu usaha yang digunakan oleh perusahaan atau pemasar untuk mengemas produk sehingga mampu menawarkan pengalaman emosi hingga menyentuh hati dan perasaan konsumen (Christian \& Dharmayanti, 2013, p. 2).

Experiential marketing memegang peranan untuk menciptakan pengalaman pelanggan. Dengan menarik bagi semua indera, dan membuat koneksi dengan cepat dan mulus, pendekatan atas tugas pemasaran ini dapat memastikan bahwa bisnis masih dapat menarik dan memenuhi kebutuhan dan keinginan konsumen (Rahayu, Wibowo, \& Christianinrum, 2013, p. 6).

Strategic Experiential Modules (SEMs) merupakan kerangka experiential marketing yang terdiri dari sense experience (indera), feel experience (perasaan), think experience (pikiran), act experience (prilaku), dan relate experience (hubungan). Lima indikator utama tersebut, dijelaskan sebagai berikut (Schmitt \& Rogers, 2008);

\section{1) Sense Experience}

Sense marketing tertuju pada memikat panca indera untuk menciptakan pengalaman sensorik melalui sight (penglihatan), sound (suara), touch (sentuhan), taste (rasa), dan smell (aroma). Sense marketing dapat digunakan untuk membedakan perusahaan dan produk, memotivasi konsumen, dan untuk menambah nilai produk.

2) Feel Experience

Feel marketing tertuju pada perasaan dan emosi pelanggan dengan bertujuan menciptakan pengalaman afektif.

Schmitt (Wibowo, 2011) Feel marketing ialah strategi dan implementasi dalam mengikat konsumen untuk senang terhadap perusahaan dan merek melalui experience provider. Agar feel marketing dapat berhasil, maka perusahaan harus mengetahui bagaimana menciptakan perasaan melalui pengalaman konsumsi. Seorang pemasar dalam menyentuh feel harus mempertimbangkan mood dan emotion pelanggan, seorang experiential marketing dikatakan berhasil apabila dapat membuat mood dan emotion pelanggan sesuai dengan keinginannya. Moods dapat diperoleh melalui rangsangan khusus di mana pelanggan tidak menyadari hal tersebut sedangkan emosi diupayakan/dilakukan secara sengaja oleh perusahaan, misalnya emosi kecemburuan, kemarahan atau bahkan cinta. Semua itu disebabkan oleh seseorang (karyawan, perusahaan, produk atau komunikasi) atau sesuatu hal secara disengaja. 


\section{3) Think Experience}

Think marketing tertuju pada intelektualitas dengan tujuan menciptakan kognitif, melalui pengalaman pemecahan masalah dengan kreativitas pelanggan. Think marketing untuk menargetkan convergent pelanggan dan berpikir divergent melalui surprise, intrigue dan provocation.

Think menciptakan aspek kognitif problem solving experience, dan think akan muncul dalam pemikiran yang divergent dan convergent melalui surprise, intrigue, dan provocation. Pikiran yang bagus akan membawa pelanggan mampu berpikir positif, sehingga memberikan opini yang positif terhadap produk dan lembaga (Alma, 2005).

\section{4) Act Experience}

Act marketing ini bertujuan untuk mempengaruhi perilaku, gaya hidup dan interaksi. Act marketing memperkaya hidup pelanggan dengan membidik pengalaman fisik mereka, memperlihatkan cara lain melakukan sesuatu, macam gaya hidup, dan interaksi. Seperti pelanggan melihat, menganalisa, pendekatan rasional untuk merubah perilaku hanya satu yang dari banyak perubahan perilaku.

5) Relate Experience

Tipe terakhir dalam SEMs adalah relate. Relate marketing bertujuan memperluas pribadi perorangan, perasaan pribadi individu, sehingga individu yang berkaitan dengan sesuatu diluar dirinya. Relate campaign menarik keinginan individu untuk perbaikan diri. Mereka mengajukan banding terhadap kebutuhan untuk dianggap positif oleh individu lain (misalnya, seseorang rekan-rekan, pacar, atau pasangan, keluarga dan rekan). Mereka menghubungkan orang ke sistem sosial yang lebih luas (subkultur, negara, dan sebagainya), sehingga membentuk kuat hubungan brand dan komunitas merek.

Menurut Schmitt bahwa "mentioned that creating a pleasant experience for customers is key to customer loyalty, and customers who agree on the experiential marketing that they have experienced are more likely to exhibit higher loyalty" menciptakan pengalaman yang menyenangkan bagi pelanggan adalah kunci loyalitas pelanggan, dan pelanggan yang setuju dengan pemasaran pengalaman yang diterimanya lebih memungkin untuk menunjukkan loyalitas yang tinggi (Öztürk, 2015).

Experiential marketing adalah suatu konsep pemasaran yang bertujuan membentuk pelanggan yang loyal dengan cara menyentuh emosi pelanggan dengan menciptakan pengalamanpengalaman positif dan memberikan suatu perasaan yang positif terhadap jasa dan produk mereka (Kartajaya, 2010).

Hal ini di dukung oleh hasil penelitian sebelumnya yang dilakukan oleh Oliver mempelajari dan menemukan, bahwa perilaku pengalaman akan menghadirkan kekuatan yang signifikan terhadap loyaltias (Guirong \& Jian, 2010).

Konsep loyalitas lebih mengarah kepada perilaku dibandingkan dengan sikap dan seorang pelanggan yang loyal akan memperhatikan perilaku pembelian yang dapat diartikan sebagai pola pembelian yang teratur dan dalam waktu yang lama, yang dilakukan oleh unit-unit pembuat atau pengambil keputusan (Mulyadi \& Saktiawati, 2006).

Loyalitas lebih mengacu pada wujud perilaku dan unit-unit pengambilan keputusan untuk melakukan pembelian secara terus menerus terhadap barang atau jasa suatu perusahaan yang dipilih (Purnama \& Afiani, 2008, p. 90)

Dimensi customer loyalty dapat dilihat dari (Griffin, 2005, p. 31):

1. Repeat purchase (pembelian ulang), yaitu pelanggan membeli produk secara teratur.

2. Refers to others (perekomendasian ke pihak lain), yaitu pelanggan secara teratur merekomendasikan kepada orang lain untuk menggunakan produk atau jasa.

3. Immunity (kekebalan), yaitu menunjukkan kekebalan dari daya tarik produk sejenis dari pesaing.

4. Purchase across product line and service (pembelian diluar lini produk atau jasa), yaitu pelanggan secara teratur membeli produk di luar produk lini atau jasa.

\section{METODE PENELITIAN}

Objek dalam penelitian ini adalah pengguna jasa treatment waxing hair removal Outlet Waxhaus Plaza Semanggi. Experiential marketing sebagai variabel independent yang terdiri dari sense experience, feel experience, think experience, act experience, relate experience. Sedangkan yang menjadi variabel dependent dalam penelitian ini adalah loyalitas pelanggan. Jenis penelitian yang digunakan ialah deskriptif dan verifikatif. Metode yang digunakan dalam penelitian ini adalah explanatory survey dengan teknik systematic random sampling dan jumlah responden sebanyak 93 orang. Teknik analisis data yang digunakan dalam penelitian ini adalah path analysis.

Teknik pengumpulan data yang digunakan adalah studi kepustakaan, observasi, wawancara, kuesioner. Sedangkan teknik analisis data yang dilakukan adalah analisis deskriptif dan verifikatif.

\section{HASIL PENELITIAN DAN PEMBAHASAN Gambaran Experiential Marketing}

Dimensi experiential marketing telah tersampaikan kepada sebagian pelanggan Outlet 
Waxhaus Plaza Semanggi. Namun dari kelima dimensi diperoleh total tertinggi ialah act experience dengan nilai sebesar 1892 atau 72,7 persen, sedangkan dimensi yang memperoleh total terendah ialah feel experience dengan nilai sebesar 1317 atau 67,4 persen. Hal tersebut mengindikasikan bahwa dimensi act experience telah memberikan kontribusi yang paling besar menguatkan experiential marketing Outlet Waxhaus Plaza Semanggi dan yang memberikan kontribusi paling kecil ialah feel experience. Selain itu gambaran secara keseluruhan experiential marketing Outlet Waxhaus Plaza Semanggi memperoleh nilai 8.607 yang termasuk kedalam kategori yang cukup tinggi.

\section{Gambaran Loyalitas Pelanggan}

Loyalitas pelanggan pengguna jasa treatment waxing hair removal Outlet Waxhaus Plaza Semanggi seperti yang diukur berdasarkan dimensi repeat purchase, refers to other, immunity, purchase across product line and service. Dari keempat dimensi diperoleh total tertinggi ialah repeat purchase dengan nilai sebesar 1485 atau 76,0 persen, sedangkan dimensi yang memperoleh total terendah ialah purchase across product line and service dengan nilai sebesar 954 atau 73,3 persen. Hal tersebut mengindikasikan bahwa dimensi repeat purchase menunjukan bahwa hampir separuhnya responden melakukan perawatan kembali di Outlet Waxhaus Plaza Semanggi. Sedangkan kontribusi yang terendah ialah dimensi purchase across product line dan service. Selain itu gambaran secara keseluruhan loyalitas pelanggan pengguna jasa treatment waxing hair removal Outlet Waxhaus Plaza Semanggi memperoleh nilai 4.377 yang termasuk kedalam kategori yang tinggi.

\section{Pengaruh Experiential Marketing Terhadap Loyalitas Pelanggan}

Besarnya pengaruh experiential marketing terhadap loyalitas pelanggan pengguna jasa treatment waxing hair removal Outlet Waxhaus Plaza Semanggi, berdasarkan hipotesis yang diuji dalam pelitian ini adalah experiential marketing dan loyaltias pelanggan. Hipotesis ini diuji secara simultan maupun parsial dengan meggunakan bantuan SPSS 23.0 for window 8.1. Adapun hasil pengujian hiportesis secara keseluruan atau simultan yang mana pengujian untuk uji $\mathrm{F}$ yang diambil dari Anova dengan tingkat probabilitas $(\mathrm{Sig})=0,000$, karena nilai $\mathrm{Sig} \leq 0,05$, dengan perolehan nilai 36.570 maka keputusannya adalah $\mathrm{H}_{0}$ ditolak. Artinya secara simultan (keseluruhan) terdapat pengaruh yang positif antara pengaruh experiential marketing terhadap loyalitas pelanggan pengguna jasa treatment waxing hair removal Outlet Waxhaus Plaza Semanggi.
Pengujian parsial dapat dilakukan setelah dipastikan adanya pengaruh yang signifikan antara experiential marketing terhadap loyalitas pelanggan pada uji simultan. Hasil korelasi antara experiential marketing terdiri dari sense experience, feel experience, think experience, act experience, relate experience terhadap loyalitas pelanggan. Diketahui bahwa total koefisien jalur dari persepsi experiential marketing terhadap loyalitas pelanggan Outlet Waxhaus Plaza Semanggi yaitu sebesar 0,678, maka dapat diketahui nilai dari koefisien residu melalui rumus:

$$
\begin{aligned}
& P_{t}=\sqrt{1-R^{2_{Y}(X 1, \ldots X 5)}} \\
& P_{t}=\sqrt{1-0,678} \\
& P_{t}=0,567
\end{aligned}
$$

Hasil tersebut menunjukkan bahwa sense experience, feel experience, think experience, act experience, relate experience, secara simultan mempengaruhi customer loyalty (Y) yaitu sebesar 67,8 persen. Sedangkan pengaruh dari luar yang tidak diteliti $(0,567) 2=0,321 \times 100 \%=32,2$ persen, dipengaruhi variabel lain yang tidak termasuk ke dalam penelitian ini.

\section{KESIMPULAN DAN REKOMENDASI}

\section{KESIMPULAN}

1. Gambaran mengenai experiential marketing dapat dilihat dari dimensi-dimensinya yang terdiri dari sense experience, feel experience, think experience, act experience, relate experience, berada pada kategori cukup tinggi.

2. Gambaran dari customer loyalty waxhaus pada responden pengguna jasa treatment waxing hair removal di Outlet Waxhaus Plaza Semanggi yang diukur berdasarkan repeat purchase, refers to other, immunity, dan purchase across product line and service secara keseluruhan berada pada kategori tinggi.

3. Experiential marketing memiliki pengaruh yang positif terhadap loyalitas pelanggan Outlet Waxhaus Plaza Semanggi dengan tingkat korelasi sebesar 67,8 persen, sedangkan untuk pengaruh variabel lain yang tidak diteliti adalah sebesar 32,2 persen. Hal ini menunjukkan bahwa semakin tinggi experiential marketing maka akan semakin tinggi pula loyalitas pelanggan Outlet Waxhaus Plaza Semanggi. 


\section{REKOMENDASI}

1. Pengalaman yang diberikan oleh Outlet Waxhaus Plaza Semanggi terlebih untuk meningkatkan relate, menyediakan suatu tempat yang lebih luas agar pelanggan bisa bersosialisasi dengan pelanggan lainnya.

2. Untuk meningkatkan keaktifan pelanggan melakukan treatment waxing hair removal, Outlet Waxhaus Plaza Semanggi bisa menyediakan suatu layanan sebagai pengingat untuk para konsumen jika sudah jatuh tempo melakukan perawatan ulang treatment waxing hair removal baik melalui phone, sms, email.

\section{DAFTAR PUSTAKA}

Alma, B. (2005). Manajemen Pemasaran dan Pemasaran Jasa (Edisi Revi). Bandung: Alfabeta.

Christian, A., \& Dharmayanti, D. (2013). Pengaruh Experiential Marketing Terhadap Customer Satisfaction Dan Customer Loyalty the Light Cup Di Surabaya Town Square, 1(2), 1-13.

Griffin, J. (2005). Customer Loyalty: Menumbuhkan dan Mempertahankan Kesetiaan Pelanggan. (A. B. D. K. Yahya, Ed.) (Edisi Revi). Jakarta: Erlanggan.

Guirong, S., \& Jian, L. (2010). An Analysis on the Effect of Supermarket Experiential Marketing Impacting Customer Loyalty. Analysis, 256-262.

Hurriyati, R., \& Widiastuti, I. (2008). Retensi Pelanggan Pada Pengunjung Resort \& Spa Kampung Sampireun Garut. Pendidikan Manajemen Bisnis, 1-19.

Kartajaya, H. (2010). Connect! Surfing new Wave Marketing. Jakarta: Gramedia Pustaka Utama.

Logahan, J. M. (2015). Customer Experience Management. Retrieved from http://sbm.binus.ac.id/2015/10/29/customer -experience-management/

Mulyadi, H., \& Saktiawati, D. (2006). Pengaruh Brand Personality Terhadap, 20-32.

Öztürk, R. (2015). Exploring the Relationships between Experiential Marketing, Customer Satisfaction and Customer Loyalty: An Empirical Examination in Konya, 9(8), 2756-2759.

Palmeira, M., Semprebom, E., Ferrari, J., Formaggi, L., Lima, L., \& Barreto, S. (2009). Track: Marketing Experiential Marketing in Bookstores An Analyses of Business Strategy and Customer Experience, 1-17.

Purnama, R., \& Afiani, F. (2008). Pengaruh Program Event Family Gathering Terhadap Loyalitas Pelanggan Bisnis Pada Hotel Nuansa Bali Anyer, 84-100.
Rahayu, A., Wibowo, L. A., \& Christianinrum. (2013). Analisis Nilai Pengalaman Berbelanja Online Melalui Experiential Marketing, 04(01), 1-15.

Same, S., \& Larimo, J. (2012). Marketing Theory: Experience Marketing and Experiential Marketing. 7th International Scientific Conference "Business and Management 2012” May 10-11, 2012, Vilnius, LITHUANIA, (March), 480-487. http://doi.org/10.3846/bm.2012.063

Schmitt, B. H., \& Rogers, D. L. (2008). Handbook on Brand and Experience Management. United Kingdom: Edward Elgar Publishing Limited.

Sumiyati, \& Purwanto, T. (2000). Pengaruh Program Jasa Berbasis Value Model MARKPLUS 2000 Terhadap Loyalitas Penumpang Maskapai GARUDA Indonesia, 50-67.

Wibowo, L. A. (2011). Experiential Marketing. Universitas Pendidikan Indonesia. 